\title{
Synthesis and biological activity of new derivatives of 6-chloro-5-((4- chlorophenyl) diazenyl) pyrimidine-2, 4-diamine and 4-chloro-6-methoxy- $N, N$-dimethylpyrimidin-2-amine
}

\author{
Nadhir Najim abdullah Jafar ${ }^{a^{*}}$, Hussein Oleiwi Muttaleb Al- \\ Dahmoshi ${ }^{\mathrm{b}}$, Ayad Mohammed Jebur Almamoori ${ }^{\mathrm{b}}$, Noor Salman \\ Kadhim Al-Khafajii ${ }^{\mathrm{b}}$ and Najim Abod Al-Masoudi ${ }^{\mathrm{c}}$ \\ ${ }^{a}$ Babylon university, College of science, Dep. of chemistry, Babylon, IRAQ \\ ${ }^{b}$ Babylon university, College of science, Dep. of Biology, Babylon, IRAQ \\ ${ }^{c}$ Basrah university, College of science, Dep. of chemistry, Basrah, IRAQ
}

\begin{abstract}
N,Ndimethylpyrimidin-2-amine has been used as precursors for the synthesis of new pyrimidine derivatives, employing Suzuki cross-coupling reaction. Thus, treatment of pyrimidine derivative with various arylboronic acids in the presence of palladium tetraacetate, $\mathrm{PhP}_{3}$ and $\mathrm{Na}_{2} \mathrm{CO}_{3}$ in refluxing n-propanol afforded the target compounds. The synthesis was supported by spectroanalytical techniques. The synthesized compounds have been screened for their inhibitory activity against some microbial, the results were showed that among gram positive isolates only (1/10) isolates of $S$. aureus and (3/10) isolates of $S$. saprophyticaus were sensitive for compound 13, while (1/10) isolates of $S$. aureus and (1/10) isolates of S.saprophyticaus were sensitive for compound 4. All isolates of $S$. pyogenes were resisting to all compounds, among gram negative bacterial isolates only (2/10) isolates of E. coli and (1/10) isolates of K. pneumoniae were sensitive to compound 4. Concerning the antifungal effects of compounds $3,4,5,13,14,15$ the results revealed that, all $C$. albicans and C. glabrata isolate were resist these compounds.
\end{abstract}

KEYWORDS: Pyrimidine, arylboronic acid, synthesis, Suzuki, gram positive

\section{INTRODUCTION}

Pyrimidine is a prominent member of the diazine family of heterocyclics. It is found throughout nature as a component of nucleic acids, nucleotides and corresponding nucleosides. Pyrimidine was first isolated by Gabriel and Colman in 1899 [1]. Pyrimidine represents one of the most active class of compounds possessing wide spectrum of biological activity viz. significant in vitro activity against unrelated DNA and RNA, viruses including polio herpes viruses, diuretic, antitumor, anti HIV, cardiovascular [2]. Methoprim, 5-(3,4,5trimethoxybenzyl)pyrimidine-2,4-diamine (1) [3], is a potent and interesting pyrimidine analogue was used, since 1980, in combination with sulfamethoxazole as a bacteriostatic antibiotic (Co-trimoxazole) and mainly prescribed in the treatment of urinary tract infections and Pneumocystis jirovecii pneumonia, the most prevalent opportunistic microorganisms afflicting individuals with HIV positive patients.

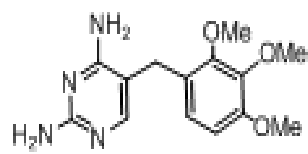

(1)

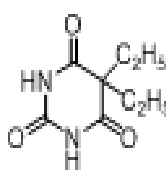

(2)<smiles>O=c1[nH]cc(F)c(=O)[nH]1</smiles>

(3)

The biodynamic property of the pyrimidine ring system prompted us to account for their pharmacological properties as antimicrobials acting against microorganisms [4]. In addition to this, pyrimidines ring is also found in vitamin B1, barbituric acid (2,4,6-trihydroxy pyrimidine) and its several derivatives e.g. Veranal 2, which are used as hypnotics [5]. In 1957, Heidelberger and Duschinsky [6] had discovered 5fluorouracil (5FU) 3 as a potential drug for tumor inhibition in mice and till update; this drug is used for treatment of cancer, in general. 


\section{Chemistry}

\section{RESULT AND DISCUSSION}

\section{SYNTHESIS OF 5-AZOARYL-4-THIOALKYL- AND 4-BENZYLHYDRAZINYL-PYRIMIDINES. 1.1. Synthesis}

The azo-pyrimidine derivative 2 have been prepared previously by Al-Masoudi et al. [7] from the commercially available 2,6-diamino-4-chloropyrimidine 1, and selected in our synthetic targets as a starting material for the synthesis of various pyrimidine analogs. Thus, treatment of $\mathbf{1}$ with $p$-chlorophenyldiazonium salt, prepared from reaction of $p$-chloroaniline with $\mathrm{NaNO}_{2}$ and $\mathrm{HCl}$ at $0-5{ }^{\circ} \mathrm{C}$, afforded 2,6-diamino-4- $(p$ chlorophenyl-azo)-4-chloropyrimidine 2. Nucleophilic substitution with primary and secondary aliphatic amines, as well as $\mathrm{O}$ - and S-nucleophiles (phenoxide and thiophenoxide ions), which are formed in situ in the reactions of phenols and thiophenols with bases, has been reported to be successful to some extent and well known [1-5]. Therefore, the presence of azo group at position 5 of compound 2 would facilitate the nucleophilic replacement of chloro group at position 4 by S-nucleophiles and amines. Treatment of 2 with $\mathrm{NaSPh}$ or $\mathrm{NaSEt}$ in DMF afforded, via nucleophilic displacements of the chlorine group, $\mathbf{3}$ and $\mathbf{4}$ in 89 and $90 \%$ yield, respectively. Similary, reaction of $\mathbf{2}$ with benzylhydrazine afforded compound $\mathbf{5}$ in $88 \%$ yields as shown in Scheme 1.

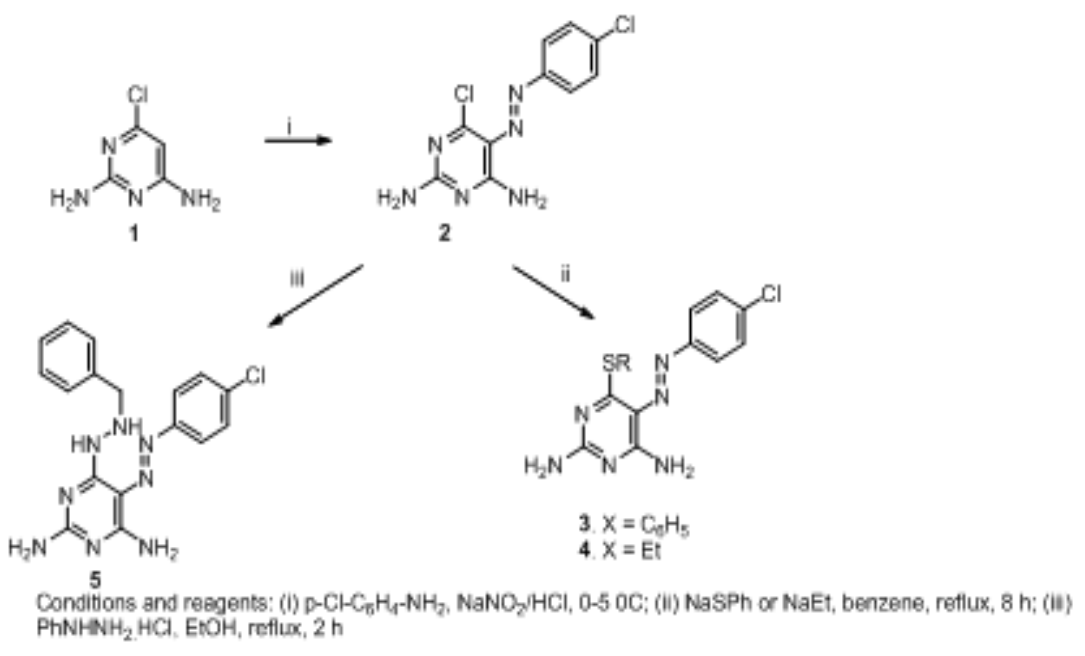

Scheme 1: Synthesis of compounds 3-5.

\subsection{1. $\quad{ }^{1} \mathrm{H}$ and ${ }^{13} \mathrm{C}$ NMR study}

Structures of compounds 3-5 were assigned by the ${ }^{1} \mathrm{H}$ and ${ }^{13} \mathrm{C}$ NMR spectra. The ${ }^{1} \mathrm{H}$ NMR spectra showed rather similar patterns for the phenyl and ethyl protons, while the singlets at $\delta=4.31-3.84$ ppm was attributed to methylene of the benzylhydrazine group. The methylene protons $\left(\mathrm{SCH}_{2}\right)$ of compound $\mathbf{4}$ appeared at $\delta 3.26(J=7.1 \mathrm{~Hz})$ as a quartet, while methyl protons $\left(\mathrm{SCH}_{3}\right)$ appeared as a triplet at $\delta=1.29 \mathrm{ppm}(J=7.1$ $\mathrm{Hz})$. The aromatic protons $\mathrm{H}-3$ and $\mathrm{H}-5$ of 3 resonated at $\delta=7.78 \mathrm{ppm}$ as a doublet $(J=7.0 \mathrm{~Hz})$, while $\mathrm{H}-2$ and H-6 appeared as a doublet at $\delta=7.54 \mathrm{ppm}(J=7.0 \mathrm{~Hz}) . \mathrm{C}_{6}-\mathrm{NH}_{2}$ and $\mathrm{C}_{2}-\mathrm{NH}_{2}$ protons resonated at $\delta=9.25$ and $8.10 \mathrm{ppm}$ as two doublets $(J=5.0$ and $5.1 \mathrm{~Hz})$, respectively. The aromatic protons of 4 resonated in the range $\delta$ $=7.90-7.80 \mathrm{ppm}$ as a multiplet, while $\mathrm{C}_{6}-\mathrm{NH}_{2}$ and $\mathrm{C}_{2}-\mathrm{NH}_{2}$ protons appeared at $\delta=9.25$ and 6.88 ppm as two broad singlets, respectively. In ${ }^{13} \mathrm{C}$ NMR spectra of $\mathbf{3}$ and $\mathbf{4}, \mathrm{C}-4$ of the pyrimidine ring resonated at $\delta=182.1$ and $\delta=164.7 \mathrm{ppm}$, respectively, while C-2, C-5 and C-6 resonated at the regions $(\delta 164.6,160.5 \mathrm{ppm}),(\delta=$ $118.5,118.7 \mathrm{ppm})$ and $(\delta=155.4,155.9 \mathrm{ppm})$, respectively. The resonances at the regions $\delta=166.9-161.0 \mathrm{ppm}$ were attributed to $\mathrm{C}-4$ and $\mathrm{C}-2$ of $\mathbf{5}$, while, the resonances at $\delta=104.7$ and $105.5 \mathrm{ppm}$ were assigned to C-5. The S-ethyl group of compound 4 were resonated at $\delta=14.5 \mathrm{ppm}\left(\mathrm{CH}_{2}\right.$ carbon atom) and $\delta=23.0 \mathrm{ppm}^{\left(\mathrm{CH}_{3}\right.}$ carbon atom). Figure 1 shows the resonances of C-2, C-4 and C-6 of compounds 3-5 in comparison for those of the 4-chloro compound 1 . The resonance of C-4 of 184 at $\delta=182.1 \mathrm{ppm}$ shifted $\sim 50 \mathrm{ppm}$, whereas the resonance of C-4 of $\mathbf{4}$ and $\mathbf{5}$ at $\delta=164.7 \mathrm{ppm}$ with shift $\sim 33 \mathrm{ppm}$. These shifts in the ${ }^{13} \mathrm{C}$ NMR resonances are indicative of chlorine replacement at $\mathrm{C}-4$ of compound $\mathbf{1}$ by the thioalkyl and hydrazinophenyl groups. 

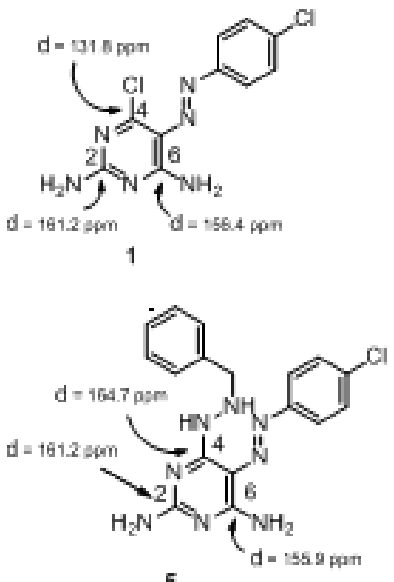
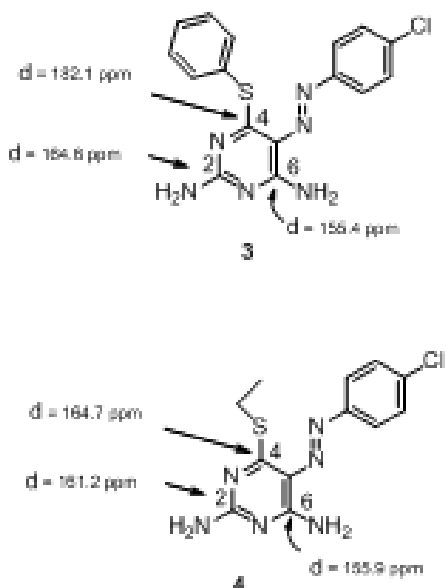

Figure 1: The resonances of carbons 2, 4 and 6 in 13C NMR spectra of compounds 3-5 in comparison for those of the starting material 1.

\section{SYNTHESIS OF 5-AZO-BIARYL-4-BENZYLHYDRAZINYL-PYRIMIDINES.}

\subsection{Synthesis}

The use of catalytic cross-coupling methodologies for preparing aryl functionalized heterocycles with pharmaceutical, agrochemical, materials and supramolecular applications is a burgeoning field of study [8]. In particular, the so-called Suzuki reaction [9-11, 12], which involves palladium catalyzed cross coupling of heteroaryl-halides with aryl boronic acids, has received considerable recent attention. We are particularly interested in exploiting the versatility of the Suzuki cross-coupling procedure to prepare new 5-azoaryl and azobiaryl-pyrimidine analogues with the aim to evaluate their biological inhibition activity. Treatment of 5 with arylboronic acids: $p$-fluorophenyl- and 3,4-dimethoxyphenylboronic acids, $\mathbf{1 6}$ and $\mathbf{9}$, respectively by applying Suzuki cross-coupling reaction, in the presence of palladium tetracetate / triphenylphosphine and $\mathrm{Na}_{2} \mathrm{CO}_{3}$ in hot $n$-propanol afforded 2,6-dimano-4-(2-benzylhydrazinyl)-5-(4'-fluoro-[1,1'-biphenyl]-4-yl)pyrimidine 7 and 4,6diamino-4-(2-benzylhdrazinyl)-5-(3',4'-dimethoxy[1,1'-biphenyl]-4-yl)pyrimidine 9 in 78 and $87 \%$ yield, respectively (Scheme 2).

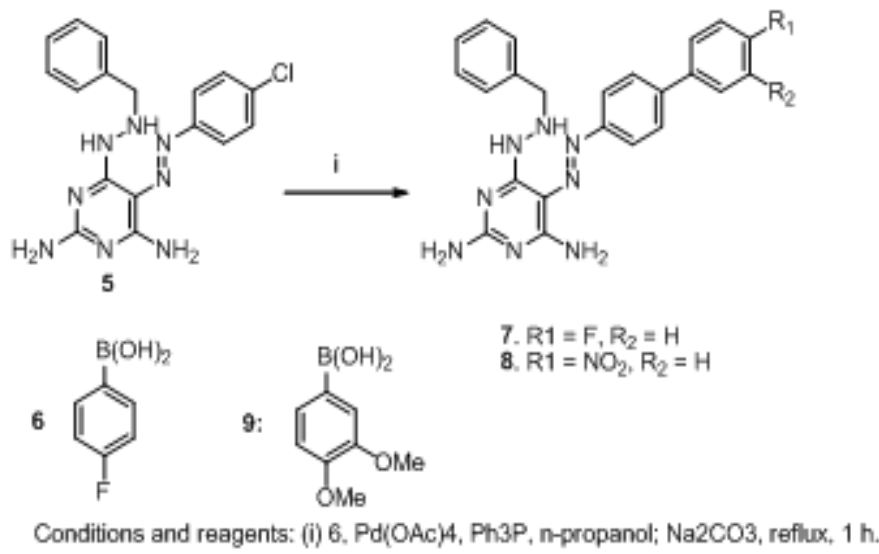

Scheme 2: Synthesis of compounds $\mathbf{7}$ and $\mathbf{8}$.

\section{2. ${ }^{1} \mathrm{H}$ and ${ }^{13} \mathrm{C}$ NMR Study}

Structures of $\mathbf{7}$ and $\mathbf{9}$ were analysed from the ${ }^{1} \mathrm{H}$ and ${ }^{13} \mathrm{C}$ NMR spectra. The ${ }^{1} \mathrm{H}$ NMR spectra showed rather similar patterns for the phenyl protons. The doublets at $\delta=4.31$ and $4.32 \mathrm{ppm}$ were assigned to methylene protons of the benzylhydrazine group $(J=5.5$ and $5.1 \mathrm{~Hz})$, respectively. $\mathrm{C}_{6}-\mathrm{NH}_{2}$ protons were appeared as broad singlets at $\delta=8.03$ and 9.41 respectively, while $\mathrm{C}_{2}-\mathrm{NH}_{2}$ together with $2 \times \mathrm{NH}$ protons were resonated at the range $\delta=7.82-7.67 \mathrm{ppm}$, and $\delta=7.68-7.46 \mathrm{ppm}$, respectively, which disappeared on $\mathrm{D}_{2} \mathrm{O}$ exchange. The multiplets at the ranges $\delta=7.68-7.46 \mathrm{ppm}$, and $\delta=7.68-7.46 \mathrm{ppm}$, were assigned to the aromatic protons for both compounds $\mathbf{7}$ and $\mathbf{9}$, respectively. In the ${ }^{13} \mathrm{C}$ NMR spectrum of 7, C-4, C-2 and C-6 were resonated at $\delta=166.9,162.1$ and $152.2 \mathrm{ppm}$, respectively, wherease $\mathrm{C}-5$ appeared at $\delta=104.7 \mathrm{ppm}$. $\mathrm{C}_{4}-\mathrm{F}$ 
and $\mathrm{C}_{1}-\mathrm{F}$ of the aromatic ring were appeared as doublets at $\delta=161.1 \mathrm{ppm}\left(J_{\mathrm{C}, \mathrm{F}}=250 \mathrm{~Hz}\right)$ and $\delta=139.2 \mathrm{ppm}$ $\left(J_{\mathrm{C}, \mathrm{F}}=2.4 \mathrm{~Hz}\right)$. Other aromatic carbon atoms resonated at the range $\delta=133.9-119.2 \mathrm{ppm}$, while mehylene carbon atom appeared at $\delta=55.4 \mathrm{ppm}$. The ${ }^{13} \mathrm{C}$ NMR spectrum of 190 showed signals at $\delta=164.5,161.0$ and $155.8 \mathrm{ppm}$ were attributed to C-4, C-2 and C- 6 of the pyrimidine backbone. The aromatic protons appeared at the range $\delta=131.9-122.9 \mathrm{ppm}$, while C-5 of the pyrimidine ring resonated at $\delta=105.5 \mathrm{ppm}$. C-1' and C-4' of the azophenyl residue appeared at $\delta=141.6 \mathrm{ppm}$, wherease $C_{3^{\prime \prime}} \mathrm{OMe}$ and $C_{4^{\prime \prime}} \mathrm{OMe}$ resonated at $\delta=149.6 \mathrm{ppm}$. $\mathrm{C}-2 "$ and C-5" of the 3,4-OMe 2 -phenyl group oriented at $\delta=113.5 \mathrm{ppm}$, and signals at $\delta=55.4 \mathrm{ppm}$ was assigned to methylene carbon.

\subsection{Synthesis}

\section{SYNTHESIS OF 5-AZOBIARYL-4-ARYLPYRIMIDINES.}

Furthermore, treatment of 2 with arylboronic acid: 4-fluorophenyl- 6, 3,4-dimethoxyphenyl- 9, 3fluorophenyl- $\mathbf{1 0}$ and 4-nirophenylboronic $\mathbf{1 1}$ acids via Suzuki cross-coupling reactions in the presence of palladium tetracetae / triphenylphosphine and $\mathrm{Na}_{2} \mathrm{CO}_{3}$ in hot $n$-propanol furnished the triaryl-pyrimidines 12-15 (92-99\% yield). (Scheme 3).

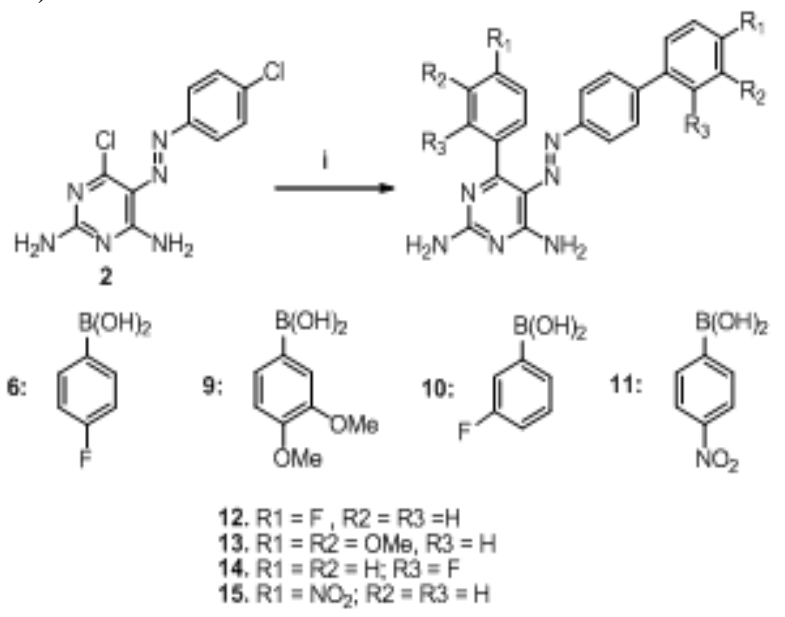

Conditions and reagents: (i) 6, 9, 10 or 11, Pd(OAc) 4, Ph3P, n-propand; Na2CO3, reflux, $1 \mathrm{~h}$.

\section{2. ${ }^{1} \mathrm{H}$ and ${ }^{13} \mathrm{C}$ NMR study}

Scheme 3: Synthesis of compounds 12-15.

Structures of the newly synthesized compounds $\mathbf{1 2 - 1 5}$ were assigned by the ${ }^{1} \mathrm{H}$ and ${ }^{13} \mathrm{C}$ NMR spectra. The ${ }^{1} \mathrm{H}$ NMR spectra showed rather similar pattern for the phenyl protons. The assignment of protons and carbons of the 12-15 were deduced from comparison with those of compounds 7 and 8 . In the ${ }^{1} \mathrm{H}$ NMR spectrum of 12, $\mathrm{NH}_{2}$ protons at C-6 and C-2 of the pyrimidine ring were appeared as two broad singlets at $\delta=9.43$ and $7.06 \mathrm{ppm}$, respectively. The aromatic protons resonated as a multiplet at the region $\delta=8.05-7.31$ $\mathrm{ppm}$, while the methoxy groups appeared as two singlets at $\delta=3.83$ and $3.74 \mathrm{ppm}$, respectively. The ${ }^{1} \mathrm{H}$ NMR spectrum of $\mathbf{1 3}$ showed two broad singlet at $\delta=9.00$ and $6.71 \mathrm{ppm}$ were assigned to $\mathrm{NH}_{2}$ protons at C-6 and C-2 of the pyrimidine ring, respectively, whereas the multiplet at the region $\delta=7.73-7.65$ was attributed to the aromatic protons. In the ${ }^{1} \mathrm{H}$ NMR of $\mathbf{1 4}, \mathrm{NH}_{2}$ protons at C-2 and C-6 resonated at $\delta=8.22$ and $7.68 \mathrm{ppm}$, respectively, while the aromatic protons appeared as a multiplet at the range $\delta=7.65-7.23 \mathrm{ppm}$. $\mathrm{NH}_{2}$ protons at C-2 and C- 6 of compound 15 were appeared as two broad singlets at $\delta=9.24$ and 6.94 ppm, respectively, whereas the aromatic protons resonated at the region $\delta=8.16-6.96 \mathrm{ppm}$. In the ${ }^{13} \mathrm{C}$ NMR spectra of compounds 12-15, C-2, C-4 and C-6 of the pyrimidine backbone were resonated at the range $\delta=168.1-163.7 \mathrm{ppm}, \delta=$ $162.2-160.0 \mathrm{ppm}$ and $\delta=160.9-155.7 \mathrm{ppm}$, respectively. C-2" bearing fluorine atom of the aromatic ring appeared at $\delta=158.5 \mathrm{ppm}$ as a doublet $\left(J_{\mathrm{C}, \mathrm{F}}=249 \mathrm{~Hz}\right)$ due to its coupling with the fluorine atom. $\mathrm{C}-5$ of the pyrimidine ring appeared at the range $\delta=122.9-119.9 \mathrm{ppm}$, while C-1" and carbon atom bearing $\mathrm{NO}_{2}$ group (C4 ") of the aromatic ring attached to the phenylazo residue resonated at $\delta=150.9 \mathrm{ppm}$. The signal at $\delta=55.1$ ppm was assigned to the methoxy groups of compound $\mathbf{1 3}$. 


\section{SYNTHESIS OF 6-ARYL- $N, N$-DIMETHYLAMINO-4-METHOXYPYRIMIDINES. 5.1. Synthesis}

2-amino-4-chloro- $N, N$-dimethylpyrimidine $\mathbf{1 6}$ has been selected as a precursor for the synthesis of new pyrimidine derivatives, employing Suzuki cross-coupling reaction, to examine the Biological inhibition activity. Thus, treatment of $\mathbf{1 6}$ with various arylboronic acids e.g.: 3-boronobenzoic acid 17, 2-fluoro- 18, 5-formylfuran2-yl- 19 and 4-nitrophenyl boronic acid 11 in the presence of palladium tetraacetate, $\mathrm{PhP}_{3}$ and $\mathrm{Na}_{2} \mathrm{CO}_{3}$ in refluxing $n$-propanol afforded $\mathbf{2 0 - 2 3}$ in $91-46 \%$ yield (Scheme 4 ).

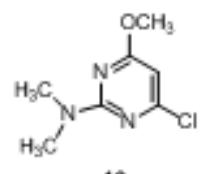

16
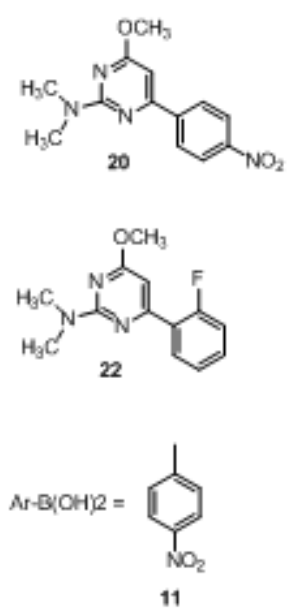
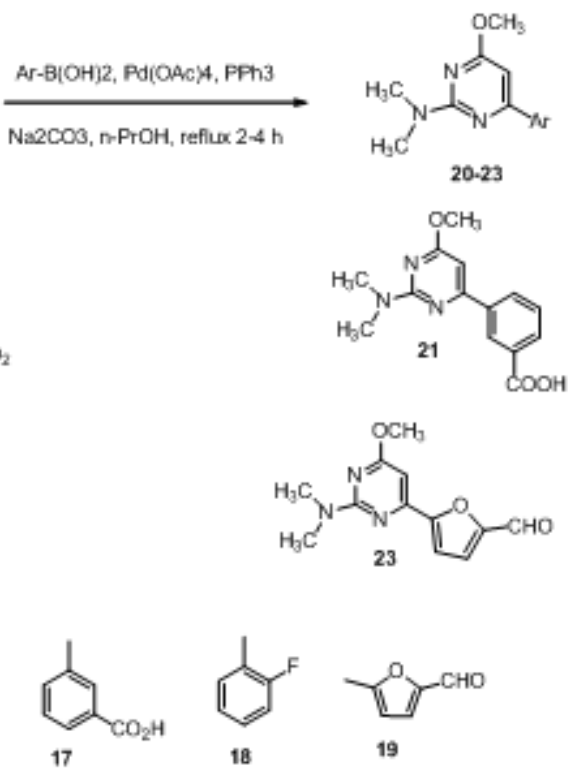

Scheme 4: Synthesis of new pyrimidine derivatives $\mathbf{2 0 - 2 3}$ from 2-amino-4-chloro-N,N-dimethylpyrimidine $\mathbf{1 6 .}$

\section{${ }^{1} \mathrm{H}$ and ${ }^{13} \mathrm{C}$ NMR Study}

The structures of 20-23 were determined from the ${ }^{1} \mathrm{H}$, and ${ }^{13} \mathrm{C}$ NMR spectra. The methyl protons $\left(\mathrm{NMe}_{2}\right)(6 \mathrm{H})$ appeared as singlets at the range $\delta=3.21-2.94 \mathrm{ppm}$, while $\mathrm{H}-5$ of the pyrimidine ring resonated at the range $\delta=6.89-6.61 \mathrm{ppm}$. The methoxy groups of compounds $\mathbf{2 0 - 2 3}$ were appeared at rang $\delta=3.92-3.74 \mathrm{ppm}$. The aromatic protons of compound $\mathbf{2 0}$ were resonated at the range $\delta=8.35-8.16 \mathrm{ppm}$. The aromatic protons of compound 21 were appeared at the range $\delta=$ 8.29-8.02 ppm, respectively. The $\mathrm{CO}_{2} \mathrm{H}$ proton of $\mathbf{2 1}$ was resonated as a singlet at $\delta=10.45 \mathrm{ppm}$. The two multiplets at the ranges $\delta=7.81-7.43$ and $7.63 \mathrm{ppm}$ were assigned to the aromatic protons of compounds 22. The 1H NMR spectrum of 23 showed a singlet at $\delta=10.54 \mathrm{ppm}$ assigned to the aldehyde protons, whereas the doublet at $\delta=8.58 \mathrm{ppm}$ attributed to $\mathrm{H}-4$ of the furan backbone $(J=$ $5.2 \mathrm{~Hz}) . \mathrm{H}-3$ of the furan ring appeared as a doublet at $\delta=7.96 \mathrm{ppm}(J=5.2 \mathrm{~Hz})$. The ${ }^{13} \mathrm{C} \mathrm{NMR}$ spectra of 20-23 contained similar resonance signals of the pyrimidine carbons ring $\mathrm{C} 2-\mathrm{C} 6$, as well as the methoxy and $\mathrm{Nme}_{2}$ carbons. Carbon atoms of methoxy and $\mathrm{Nme}_{2}$ pyrimidine ring of compounds 20-23 resonated at the ranges $\delta=53.8-53.4 \mathrm{ppm}$ and $\delta=37.0-36.4 \mathrm{ppm}$, respectively. In the ${ }^{13} \mathrm{C}$ NMR spectrum of 20, the signal at $\delta=162.2 \mathrm{ppm}$ was assigned to C-2 and C- 6 of the pyrimidine ring, whereas signals at $\delta=171.2$ and $92.5 \mathrm{ppm}$ were attributed to C-4 and C-5 of he same ring. $148.8\left(\mathrm{C}_{4},-\mathrm{NO}_{2}\right)$ and other aromatic ring 1,2 and 6,3 and 5 were oriented at $\delta=143.8$, 128.4; and $124.1 \mathrm{ppm}$, respectively. The ${ }^{13} \mathrm{C}$ NMR of compound 21 was characterized by the presence of downfield signal at $\delta=173.4 \mathrm{ppm}$, assigned o the $\mathrm{CO}_{2} \mathrm{H}$ group. C-2, C-4, C-5 and C-6 of the pyrimidine ring were oriented at $\delta=161.7,170.5,91.4$ and $162.7 \mathrm{ppm}$, respectively.

The aromatic carbon atoms were appeared at the range $132.2-128.7 \mathrm{ppm}$. The ${ }^{13} \mathrm{C}$ NMR spectrum of 22 showed signal at $\delta=161.2,171.8,95.0$ and 164.4 ppm were assigned to C-2, C-4, C5 and C- 6 of the pyrimidine backbone, respectively, whereas the doublet at $\delta=156.6\left(J_{\mathrm{C} 2, \mathrm{~F}}=251\right.$ 
$\mathrm{Hz}$ ) was attributed to the aromatic atom C-2 attached to fluorine atom. The multiplet at the range $\delta=$ 129.2-115.1 ppm was assigned to the aromatic carbon atoms and their couplings with the fluorine atom at-C-2.The ${ }^{13} \mathrm{C}$ NMR of compound 23 characterized by the presence of the down-field signals at $\delta=178.5 \mathrm{ppm}$ were assigned to $\mathrm{CHO}$ group,. C-2 of the pyrimidine ring were resonated at $\delta=$ $163.1 \mathrm{ppm}$, while C-4 appeared at $\delta=170.3 \mathrm{ppm}, \mathrm{C}-5$ of this compound resonated at $\delta=102.3$ ppm, whereas C- 6 of the pyrimidine ring appeared at $\delta=167.4 \mathrm{ppm}$. The signals at $\delta=161.1,111.8$, 124.6 and $152.3 \mathrm{ppm}$ were assigned to the carbon atoms 1-4 of the furan ring. The structure of $\mathbf{2 0}$ was further confirmed by the 2D NMR study (heteronuclear Single Quantum Correlation (HSQC) [13]. From the ${ }^{1} \mathrm{H},{ }^{13} \mathrm{C}-\mathrm{HSQC}$ spectrum of compound 20, the singlets of $\mathrm{H}-5$, Ome and $\mathrm{Nme}_{2}$ at $\delta=$ 6.72, 3.92 and $3.21 \mathrm{ppm}$ were coupled to C-5, carbon of Ome and carbon of $\mathrm{Nme}_{2}$ groups at $\delta=$ 92.5, 53.5 and $36.9 \mathrm{ppm}$, respectively. The multiplet for aromatic protons at $\delta=8.35-8.16 \mathrm{ppm}$ were coupled to the aromatic carbons C-3, C-5 and C-2, C-6 at $\delta=128.4$ and $124.1 \mathrm{ppm}$, respectively.

\section{Biology}

Microbiological resistance refers to nonsusceptibility of a fungus to an antifungal agent by in vitro susceptibility testing, in which the MIC of the drug exceeds the susceptibility breakpoint for that organism. Microbiological resistance can be primary (intrinsic) or secondary (acquired). Primary resistance is found naturally among certain fungi without prior exposure to the drug and emphasizes the importance of identification of fungal species from clinical specimens. Examples include resistance of Candida krusei to fluconazole and of Cryptococcus neoformans to echinocandins. Secondary resistance develops among previously susceptible strains after exposure to the antifungal agent and is usually dependent on altered gene expression. The development of fluconazole resistance among Candida albicans and C. neoformans strains illustrates this type of [14]. The four main mechanisms by which microorganisms exhibit resistance to antimicrobials are: Drug inactivation or modification, Alteration of target site, Alteration of metabolic pathway and Reduced drug accumulation: by decreasing drug permeability and/or increasing active efflux (pumping out) of the drugs across the cell surface [15] Regarding the tested compounds of series 1, as depicted in table (1) and figure (2) the results of agar well diffusion method display that among gram positive isolates only (1/10) isolates of $S$. aureus and (3/10) isolates of $S$. saprophyticaus were sensitive for compound $\mathbf{1 3}$ while (1/10) isolates of $S$. aureus and (1/10) isolates of $S$. saprophyticaus were sensitive for compound $\mathbf{4}$ with inhibition zone more than $12 \mathrm{~mm}$. All isolates of $S$. pyogenes were resisting to all compounds $\mathbf{3 , 4 , 5 , 1 3 , 1 4}$ and $\mathbf{1 5}$ as shown in figure (2). Table (1): Inhibition zone diameter ( $\mathrm{mm}$ ) of $\mathbf{3 , 4 , 5 , 1 3 , 1 4}$ and 15 synthetic organic compounds. 
Synthesis and biological activity of new derivatives of...

\begin{tabular}{|c|c|c|c|c|c|c|c|c|c|}
\hline \multirow{3}{*}{ 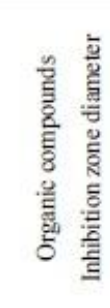 } & \multirow{3}{*}{ 豆 } & \multicolumn{3}{|c|}{ Gram Positive Isolates } & \multicolumn{3}{|c|}{ Gram Negative Isolates } & \multicolumn{2}{|c|}{ Yeast } \\
\hline & & $\begin{array}{l}\text { है } \\
\text { है } \\
\text { v. }\end{array}$ & 的 $\frac{\mathrm{c}}{\mathrm{c}}$ & $\begin{array}{l}\text { है } \\
\text { है } \\
\text { है }\end{array}$ & $\begin{array}{l}\text { है } \\
\text { सी }\end{array}$ & $<\frac{5}{8}$ & 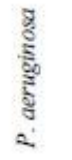 & 产 & $\frac{\text { गू }}{\frac{3}{3}}$ \\
\hline & & $n=10$ & $n=10$ & $n=5$ & $\begin{array}{c}n=1 \\
0\end{array}$ & $n=10$ & $n=10$ & $\begin{array}{c}n=1 \\
0\end{array}$ & $n=3$ \\
\hline \multirow{6}{*}{ 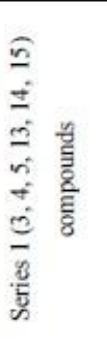 } & $\mathrm{Cl}$ & 0.00 & 0.00 & 0.00 & 0.00 & 0.00 & 0.00 & 0.00 & 0.00 \\
\hline & $\mathrm{C} 2$ & 0.00 & 0.00 & 0.00 & 0.00 & 0.00 & 0.00 & 0.00 & 0.00 \\
\hline & $\mathrm{C} 3$ & $\begin{array}{c}13 m \\
m\end{array}$ & $\begin{array}{c}15 m \\
m\end{array}$ & 0.00 & 0.00 & 0.00 & 0.00 & 0.00 & 0.00 \\
\hline & $\mathrm{C} 4$ & 0.00 & 0.00 & 0.00 & 0.00 & 0.00 & 0.00 & 0.00 & 0.00 \\
\hline & $\mathrm{C} 5$ & $\begin{array}{c}15 m \\
m\end{array}$ & $\begin{array}{c}16 m \\
m\end{array}$ & 0.00 & $\begin{array}{c}14 m \\
m\end{array}$ & $\begin{array}{c}16 m \\
m\end{array}$ & 0.00 & 0.00 & 0.00 \\
\hline & C6 & 0.00 & 0.00 & 0.00 & 0.00 & 0.00 & 0.00 & 0.00 & 0.00 \\
\hline \multirow{8}{*}{ 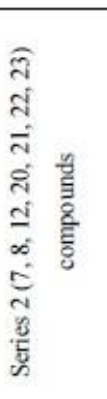 } & C7 & 0.00 & 0.00 & 0.00 & 0.00 & 0.00 & 0.00 & 0.00 & 0.00 \\
\hline & C8 & 0.00 & 0.00 & 0.00 & 0.00 & 0.00 & 0.00 & 0.00 & 0.00 \\
\hline & C9 & $\begin{array}{c}13 m \\
m\end{array}$ & $\begin{array}{c}14 m \\
m\end{array}$ & 0.00 & $\begin{array}{c}15 m \\
m\end{array}$ & $\begin{array}{c}13 m \\
m\end{array}$ & 0.00 & $\begin{array}{c}14 m \\
m\end{array}$ & 0.00 \\
\hline & $\mathrm{C} 10$ & 0.00 & 0.00 & 0.00 & 0.00 & 0.00 & 0.00 & 0.00 & 0.00 \\
\hline & C11 & 0.00 & 0.00 & 0.00 & 0.00 & 0.00 & 0.00 & 0.00 & 0.00 \\
\hline & $\mathrm{C} 12$ & 0.00 & 0.00 & 0.00 & 0.00 & 0.00 & 0.00 & 0.00 & $12 \mathrm{~mm}$ \\
\hline & $\mathrm{C} 13$ & 0.00 & 0.00 & 0.00 & 0.00 & 0.00 & 0.00 & 0.00 & 0.00 \\
\hline & C14 & 0.00 & 0.00 & 0.00 & 0.00 & 0.00 & 0.00 & 0.00 & 0.00 \\
\hline
\end{tabular}

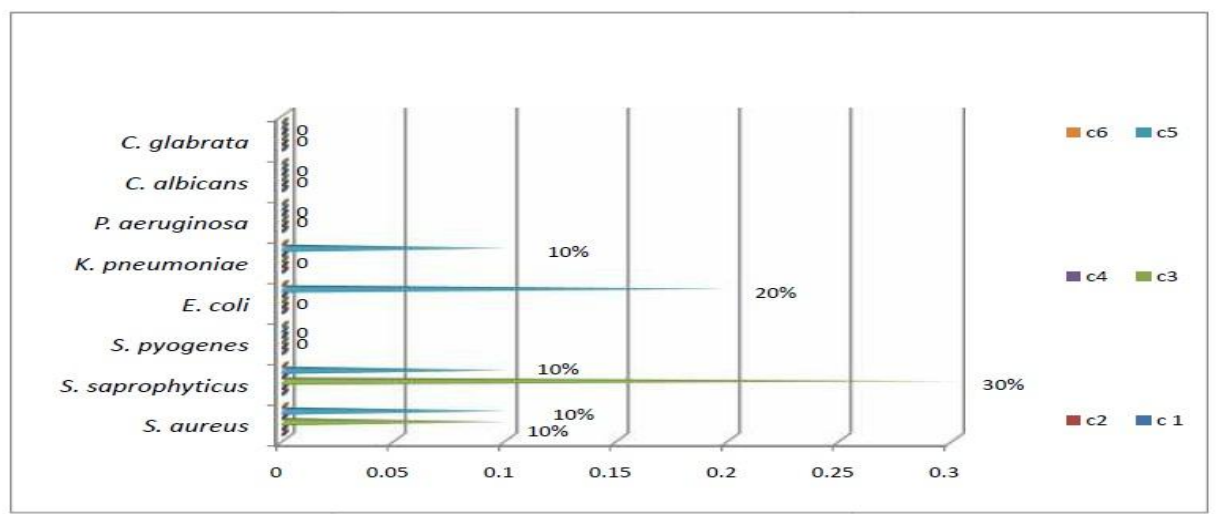

Figure 2: Percentage of sensitive microbial isolates to $\mathbf{3 , 4 , 5 , 1 3 , 1 4}$ and $\mathbf{1 5}$ synthetic organic compounds.

Clinical resistance is defined as the failure to eradicate a fungal infection despite the administration of an antifungal agent with in vitro activity against the organism. Such failures can be attributed to a combination of factors related to the host, the antifungal agent, or the pathogen. Although clinical resistance cannot always be predicted, it highlights the importance of individualizing treatment strategies on the basis of the clinical situation [16].

There are four major mechanisms of resistance to azoles have been described in Candida species: Decreased drug concentration. The first one is development of active efflux pumps results in decreased drug concentrations at the site of action. Efflux pumps are encoded in Candida species by 2 gene families of transporters: the CDR genes of the ATP binding cassette super family, and the MDR genes of the major facilitator's class. The second mechanism is Target site alteration. It has been demonstrated that mutations in ERG11, the gene encoding for the target enzyme lanosterol C14a-demethylase, prevents binding of azoles to the enzymatic site [17].Among gram negative bacterial isolates only (2/10) isolates of E. coli and (1/10) isolates of $K$. pneumoniae were sensitive to compound 4 with inhibition zone more than $12 \mathrm{~mm}$. Concerning the antifungal effects of $\mathbf{3}, \mathbf{4 , 5}, \mathbf{1 3}, \mathbf{1 4}$ and $\mathbf{1 5}$ compounds the results revealed that, all $C$. albicans and $C$. glabrata isolate were resist these compounds. 
The third mechanism is up-regulation of target enzyme. Some Candida isolates with reduced susceptibility to azoles have higher intracellular concentrations of ERG11p than do azole-susceptible strains. The antifungal agent is, therefore, overwhelmed and routine therapeutic concentrations can no longer effectively inhibit ergosterol synthesis [18]. Target enzyme up-regulation can be achieved through gene amplification, increased transcription rate, or decreased degradation of the gene product. The last mechanism of antifungal resistance is development of bypass pathways. Exposure to azole compounds results in depletion of ergosterol from the fungal membrane and accumulation of the toxic product 14a-methyl-3,6-diol, leading to growth arrest[19].

As presented in figure (3) the susceptibility results of microbial isolates to 7, 8, 12, 20, 21, 22, and 23 synthetic organic compounds revealed that (2/10) isolates of each of the $S$. aureus, S. saprophyticus and E. coli while (1/10) isolates of each of $K$. pneumoniae and $C$. albicans were sensitive to compound $\mathbf{8}$ with inhibition zone more than $12 \mathrm{~mm}$. Only one isolate of C. glabrata was sensitive to compound 20 with inhibition zone more than $12 \mathrm{~mm}$.

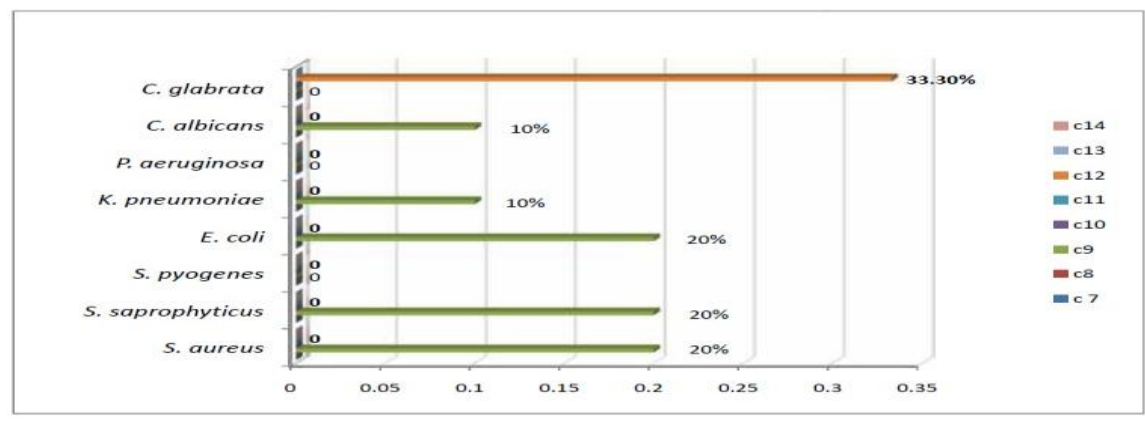

Figure 3: Percentage of sensitive microbial isolates to $\mathbf{3 , 4 , 5 , 1 3 , 1 4}$ and 15 synthetic organic compounds.

We conclude that some of the synthetic organic compounds have both antibacterial and antifungal activity and can be used for treatments after achieving toxicity and safety tests. Structural modification of these compounds might optimize their biological activity by introducing diverse and potent functional group at pyrimidine back bone.

\section{Chemistry}

\section{EXPERIMENTAL SECTION}

\subsection{General remarks}

Melting points are uncorrected and were measured on a Stuart melting point apparatus (SMP30, England). The nuclear magnetic resonance data were obtained 400 and $600 \mathrm{MHz}\left({ }^{1} \mathrm{H}\right)$ and $150.91 \mathrm{MHz}\left({ }^{13} \mathrm{C}\right)$ spectrometers (Avance III, Bruker, Germany), Tetramethylsilane TMS used as internal reference. The spectral data were reported in delta $(\delta)$ scale in ppm units relative to TMS reference line. Multiplicities $(\mathrm{s}=\operatorname{singlet}, \mathrm{d}=$ doublet, $\mathrm{t}=$ triplet, $\mathrm{q}=$ quartet and $\mathrm{m}=$ multiples). Heteronuclear assignments were verified by ${ }^{1} \mathrm{H}-{ }^{13} \mathrm{C} \mathrm{HSQC}$ experiments. Microanalytical data were obtained with a Vario, Elemental apparatus (Shimadzu, Japan). Thin layer chromatography (TLC) was carried out using TLC-silica plates GOF254 (0.2 mm) of the Merck Company. The detection was followed by UV-Lamp at $254 \mathrm{~nm}$ or through coloring with iodine. The chromatographic separations were carried out using silica gel (60-230 mesh). The ratio of the solvent and mixed mobile phases was given in volume ratio.

\subsection{Solvents}

Solvents were dried and purified by conventional methods prior to use. Acetone was dried and distilled prior to use from phosphorus pentaoxide $\left(\mathrm{P}_{2} \mathrm{O}_{5}\right)$. Chloroform and dichloromethane were dried and distilled over dry Calcium chloride, collected over magnesium sulphate then filtered over magnesium sulphate. All of these solvent obtained from Scharalau. But Hexane, Ethanol, Methanol, Propanol, DMF obtained from Thomas Baker (chemicals) limited. Whereas THF and ethyl acetate were obtained from a BDH Chemical Ltd (pode England).

\subsection{Chemicals}

6-chloro-5-((4-chlorophenyl)diazenyl)pyrimidine-2,4-diamine were given from Prof. Najim AlMasoudi prepared by same procedure puplished in .J.Med.Chem [7].

6-chloro-1,3-dimethyl-5-nitropyrimidine-2,4(1H,3H)-dione,2,6-Diamino-4-chloro-pyrimidine and all arylboronic acids listed below were purchased from Sigma-Aldrich. 
Synthesis and biological activity of new derivatives of...

\section{4. synthesis}

Preparation of 2,6-diamono-4-chloro-5-p-chlorophenylazopyrimidine (2).

The compound was prepared by method described in reference [7] from the commercially available 2,6diamino-4-chloropyrimidine $2(2.55 \mathrm{~g}, 20 \mathrm{mmol})$ in $6 \mathrm{~N} \mathrm{HCl}(10 \mathrm{~mL})$ and p-chlorophenyldiazonium salt [from $\mathrm{NaNO}_{2}(1.38 \mathrm{~g}, 20 \mathrm{mmol})$ in water $(6 \mathrm{~mL})$ at $0{ }^{\circ} \mathrm{C}$. Yield: $78 \%$, m.p. $267^{\circ} \mathrm{C}$, Lit. $268{ }^{\circ} \mathrm{C}$.

\section{2, 6-Diamino-6-phenylthio-5-p-chlorophenylazopyrimidine (3).}

A solution of $2(250 \mathrm{mg}, 0.89 \mathrm{mmol})$ in benzene $(20 \mathrm{~mL})$ containing $\mathrm{NaSPh}(110 \mathrm{mg}, 0.89 \mathrm{mmol})$ was heated under reflux. After for $8 \mathrm{~h}$, the color of solution was changed into an yellow color, where the completion of reaction was monitored by TLC. After cooling, the solution was concentrated and left overnight at low temperature. The yellow crystals werecollected and recrystallized from EOH to give 3 (281 mg, 89\%), m.p. 237-238 ${ }^{\circ} \mathrm{C}$. ${ }^{1} \mathrm{H}$ NMR (DMSO- $d_{6}$ ): $\delta=9.25$ (br s., $\left.2 \mathrm{H}, \mathrm{C}_{6}-\mathrm{NH}_{2}\right) ; 7.90-7.30$ (m, 9H, $\mathrm{H}_{\text {arom }}$ ), 6.88 (br s., $2 \mathrm{H}, \mathrm{C}_{2-}$ $\left.\mathrm{NH}_{2}\right) .{ }^{13} \mathrm{C}$ NMR (DMSO- $\left.d_{6}\right): \delta=182.1(\mathrm{C}-4) ; 164.6(\mathrm{C}-2) ; 155.4(\mathrm{C}-6) ; 139.8\left(\mathrm{C}_{\text {arom }}-\mathrm{Cl}\right) ; 133.4\left(\mathrm{C}^{1 "}\right.$ arom $\left.^{-\mathrm{S}}\right)$; $129.4,129.3,128.7,128.3,127.5,125.4,124.1,122.9\left(\mathrm{C}_{\text {arom }}\right) ; 118.5$ (C-5). Anal. calcd. For $\mathrm{C}_{16} \mathrm{H}_{13} \mathrm{ClN}_{6} \mathrm{~S}$ (356.83): C, 53.85; H, 3.67; N, 23.55. Found; C, 53.53; H, 3.54; N, 23.72.

\section{2,6-Diamino-4-ethylthio-5-p-chlorophenylazapyrimidine (4).}

Method was analogues to the proceeding procedure, using instead $2(250 \mathrm{mg}, 0.87 \mathrm{mmol})$ and NaSEt (74 mg, $0.887 \mathrm{mmol})$. Yield: $235 \mathrm{mg}$ (90\%), m.p. 267-268 ${ }^{\circ} \mathrm{C} .{ }^{1} \mathrm{H}$ NMR (DMSO- $\left.d_{6}\right): \delta=9.25(\mathrm{~d}, 2 \mathrm{H}, J=5.0$ $\left.\mathrm{Hz}, \mathrm{C}_{6}-\mathrm{NH}_{2}\right) ; 8.10\left(\mathrm{~d}, 2 \mathrm{H}, J=5.1 \mathrm{~Hz}, \mathrm{C}_{2}-\mathrm{NH}_{2}\right) ; 7.78\left(\mathrm{~d}, 2 \mathrm{H}, J=7.0 \mathrm{~Hz}, \mathrm{H}_{\text {arom }}-3+\mathrm{H}_{\text {arom }}-5\right) ; 7.54(\mathrm{~d}, 2 \mathrm{H}, J=7.0$ $\left.\mathrm{Hz}, \mathrm{H}_{\text {arom }}-2+\mathrm{H}_{\text {arom }}-6\right) .{ }^{13} \mathrm{C}$ NMR (DMSO- $\left.d_{6}\right): \delta=164.7(\mathrm{C}-4) ; 161.2(\mathrm{C}-2) ; 155.9(\mathrm{C}-6) ; 133.5\left(\mathrm{C}_{\text {arom }}-\mathrm{Cl}\right)$; 129.3, $123.3\left(\mathrm{C}_{\text {arom }}\right) ; 118.7$ (C-5). Anal. calcd. For $\mathrm{C}_{12} \mathrm{H}_{13} \mathrm{ClN}_{6} \mathrm{~S}$ (308.79): C, 46.68; H, 4.24; N, 27.22. Found; C, 46.38; H, 4.18; N, 27.39.

\section{2,6-Diamino-4-(2-benzylhydrazinyl)-5-p-chlorophenylazopyrimidine (5).}

To a solution of $2(1.0 \mathrm{~g}, 3.54 \mathrm{mmol})$ in EtOH $(30 \mathrm{~mL})$ was added benzylhydrazine hydrochloride $(0.45 \mathrm{~g}, 2.84 \mathrm{mmol})$ and the mixture was heated under reflux for $2 \mathrm{~h}$. After cooling, the orange solution was concentrated and left overnight at $0{ }^{\circ} \mathrm{C}$. The orange crystals werre filtered, and recrystallized from EtOH to give 8 (1.14 g, 88\%), m.p. 211-215 ${ }^{\circ} \mathrm{C} .{ }^{1} \mathrm{H}$ NMR (DMSO- $\left.d_{6}\right): \delta=9.31$ (br s., $\left.2 \mathrm{H}, \mathrm{C}_{6}-\mathrm{NH}_{2}\right), 9.00-8.96$ (m, $2 \mathrm{H}$, $2 \mathrm{xNH}$ ); 8.26 (br s., $\left.2 \mathrm{H}, \mathrm{C}_{4}-\mathrm{NH}_{2}\right) ; 7.99-7.35\left(\mathrm{~m}, 9 \mathrm{H}, \mathrm{H}_{\text {arom }}\right) ; 4.06\left(\mathrm{~s}, 2 \mathrm{H}, \mathrm{CH}_{2}\right) .{ }^{13} \mathrm{C}$ NMR (DMSO- $\left.d_{6}\right): \delta=164.7$

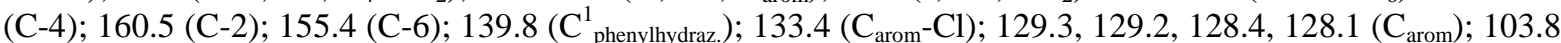
(C-5); $53.6\left(\mathrm{CH}_{2}\right)$. Anal. calcd. For $\mathrm{C}_{17} \mathrm{H}_{17} \mathrm{ClN}_{8}$. (368.82): C, 55.36; H, 4.65; N, 30.38. Found C, 55.36; H, 4.50; $\mathrm{N}, 30.21$.

\subsection{General procedure of Suzuki reaction for preparation of 7 and 12- 15.}

\section{2,6-Diamino-4-(2-benzylhydrazinyl)-5-(4'-fluoro-[1,1'-biphenyl]-4-yl) pyrimidine (7).}

A mixture of halopyrimidine and arylboronic acid in $n$-propanol $(15 \mathrm{~mL})$ was stirred for $15 \mathrm{~min}$. To this mixture was added $\mathrm{Pd}(\mathrm{OAc})_{4}(650 \mathrm{mg}, 0.19 \mathrm{mmol})$, triphenylphosphene $(498 \mathrm{mg}, 0.19 \mathrm{mmol})$ and $2 \mathrm{M}$ aq. solution of $\mathrm{Na}_{2} \mathrm{CO}_{3}(3.5 \mathrm{~mL})$. The reaction mixture was refluxed under nitrogen for 4-6 $\mathrm{h}$ and completion of reaction was monitored by TLC. After cooling, water was added $(7 \mathrm{~mL})$, followed by stirring for $5 \mathrm{~min}$. The mixture was partitioned with ethyl acetate $(3 \times 10 \mathrm{~mL})$ and the combined organic layers were washed subsequently with $5 \% \mathrm{Na}_{2} \mathrm{CO}_{3}$ solution $(2 \times 10 \mathrm{~mL})$, brine solution $(2 \times 10 \mathrm{~mL})$ and finally with water $(10 \mathrm{~mL})$. The organic phase was decolorized with charcoal, filtered and the filtrate was dried $\left(\mathrm{Na}_{2} \mathrm{SO}_{4}\right)$, filtered through celite and evaporated to dryness to give, after purification, the desired product.From 5 (70 $\mathrm{mg}, 0.19 \mathrm{mmol})$ and p-fluorophenylboronic acid $6(27 \mathrm{mg}, 0.19 \mathrm{mmol})$. Yield: $63 \mathrm{mg}(78 \%)$, as a brown crystals, m.p. $180-182{ }^{\circ} \mathrm{C}$ $(\mathrm{dec}), \mathrm{R}_{\mathrm{f}}=0.67$ (eluent: etheyl acetate/ hexane 3:2). ${ }^{1} \mathrm{H}$ NMR (DMSO- $d_{6}$ ): $\delta=8.03$ (br s., $2 \mathrm{H}, \mathrm{C}_{6}-\mathrm{NH}_{2}$ ). $7.82-$ $7.67\left(\mathrm{~m}, 4 \mathrm{H}, \mathrm{C}_{2}-\mathrm{NH}_{2}+2 \mathrm{xNH}\right) ; 7.64-7.31\left(\mathrm{~m}, 13 \mathrm{H}, \mathrm{H}_{\text {arom }}\right) ; 4.31\left(\mathrm{~d}, 2 \mathrm{H}, J=5.5 \mathrm{~Hz}, \mathrm{CH}_{2}\right) .{ }^{13} \mathrm{C}$ NMR $\left(\mathrm{DMSO}-d_{6}\right)$ : $\delta=166.9(\mathrm{C}-4) ; 162.1(\mathrm{C}-2) ; 161.1\left(\mathrm{~d}, J_{\mathrm{C} 4 ", \mathrm{~F}}=250 \mathrm{~Hz}, \mathrm{C}_{4 "-\mathrm{F}}\right) ; 152.2(\mathrm{C}-6) ; 139.5\left(\mathrm{C}-4^{\prime}+\mathrm{C}_{\text {phenylhydraz. }}^{1}\right) ; 139.2$ $\left(\mathrm{d}, J_{\mathrm{C}-1 ", \mathrm{~F}}=2.4 \mathrm{~Hz}, \mathrm{C}-1 "\right) ; 133.9,133.1,131.9,131.4,129.2,128.7,128.6,127.2,119.2\left(\mathrm{C}_{\text {arom }}\right) ; 104.7(\mathrm{C}-5)$; 55.4 $\left(\mathrm{CH}_{2}\right)$. Anal. calcd. For $\mathrm{C}_{23} \mathrm{H}_{21} \mathrm{FN}_{8}$ (428.46): C, 64.47; H, 4.94; N, 26.15. Found: C, 64.24; H, 4.90; N, 25.94.

\section{2,6-Diamino-4-(3,4-dimethoxyphenyl)-5-(3,4-dimethoxy[1,1'-biphenyl]-4-yl) pyrimidine (8).}

From 5 (122 mg, $0.40 \mathrm{mmol}$ ) and 3,4-dimethoxyphenylboronic acid $\mathbf{9}$ (155 mg, $0.85 \mathrm{mmol})$. Yield: 193 $\mathrm{mg}(92 \%)$, as a red crystals, m.p. $165-166{ }^{\circ} \mathrm{C}, \mathrm{R}_{\mathrm{f}}=0.54$ (eluent: etheyl acetate/ hexane 3:2). ${ }^{1} \mathrm{H}$ NMR (DMSO$\left.d_{6}\right): \delta=9.00$ (br s, $\left.2 \mathrm{H}, \mathrm{C}_{6}-\mathrm{NH}_{2}\right) ; 7.73-7.65\left(\mathrm{~m}, 10 \mathrm{H}, \mathrm{H}_{\text {arom }}\right) ; 6.71$ (br s, $\left.2 \mathrm{H}, \mathrm{C}_{2}-\mathrm{NH}_{2}\right) ; 3.83,3.76,3.74(\mathrm{~m}, 12 \mathrm{H}$, $4 \times \mathrm{OMe}) .{ }^{13} \mathrm{C}$ NMR (DMSO- $\left.d_{6}\right): \delta=163.7(\mathrm{C}-2) ; 161.7(\mathrm{C}-4), 160.9(\mathrm{C}-6), 151.8,147.0(4 \times C$-OMe); $141.0(\mathrm{C}-$ $\left.1^{\prime}\right) ; 131.9,131.4,131.3,129.2,128.7,128.5\left(\mathrm{C}_{\text {arom }}\right) ; 122.9(\mathrm{C}-5) ; 113.5,112.1,110.3\left(\mathrm{C}_{\text {arom }}\right) ; 55.1(4 \times \mathrm{OMe})$. Anal. calcd. for $\mathrm{C}_{26} \mathrm{H}_{26} \mathrm{~N}_{6} \mathrm{O}_{4}$ (486.52): C, 64.19; H, 5.39; N, 17.27. Found: C, 64.56; H, 5.31; N, 17.20. 
2,6-Diamino-4-(4-fluorophenyl)-5-(4-fluoro[1,1'-biphenyl]-4-yl) pyrimidine (12).

From 2 (86 mg, $0.30 \mathrm{mmol})$ and 4-Flurophenylboronic acid 6 (85 mg, $0.60 \mathrm{mmol})$ Yield: $93 \mathrm{mg}$ (76\%), as a red crystals, m.p. $179-180{ }^{\circ} \mathrm{C}, \mathrm{R}_{\mathrm{f}}=0.70$ (eluent: etheyl acetate/ hexane $2: 1$ ). ${ }^{1} \mathrm{H}$ NMR $\left(\mathrm{DMSO}-d_{6}\right)$ : $\delta=9.43$ (br s, $\left.2 \mathrm{H}, \mathrm{C}_{6}-\mathrm{NH}_{2}\right)$ 8.05-7.31 (m, $12 \mathrm{H}, \mathrm{H}_{\text {arom }}$ ); 7.06 (br s, $\left.2 \mathrm{H}, \mathrm{C}_{2}-\mathrm{NH}_{2}\right) .{ }^{13} \mathrm{C} \mathrm{NMR}\left(\mathrm{DMSO}-d_{6}\right): \delta=$

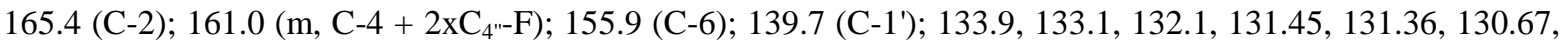
129.9, $127.2\left(\mathrm{C}_{\text {arom }}\right) ; 122.3(\mathrm{C}-5) ; 120.8,116.2,115.3\left(\mathrm{C}_{\mathrm{arom}}-\mathrm{c}+\mathrm{C}_{\mathrm{arom}}-\mathrm{e}+\mathrm{C}-3 "+\mathrm{C} 5 "\right)$. Anal. calcd. For $\mathrm{C}_{22} \mathrm{H}_{16} \mathrm{~F}_{2} \mathrm{~N}_{6}$ (402.40): C, 65.66; H, 4.01; N, 20.88. Found: C, 65.42: H, 3.96; N, 20.65.

\section{2,6-Diamino-4-(3,4-dimethoxyphenyl)-5-(3,4-dimethoxy[1,1'-biphenyl]-4-yl) pyrimidin(13).}

From 2 (122 mg, $0.40 \mathrm{mmol})$ and 3,4-dimethoxyphenylboronic acid 9 (155 mg, $0.85 \mathrm{mmol})$. Yield: $193 \mathrm{mg}(92 \%)$, as a red crystals, m.p. $165-166{ }^{\circ} \mathrm{C}, \mathrm{R}_{\mathrm{f}}=0.54$ (eluent: etheyl acetate/ hexane $3: 2$ ). ${ }^{1} \mathrm{H}$ NMR (DMSO- $d_{6}$ ): $\delta=9.00$ (br s, $2 \mathrm{H}, \mathrm{C}_{6}-\mathrm{NH}_{2}$ ); $7.73-7.65$ (m, 10H, $\mathrm{H}_{\text {arom }}$ ); 6.71 (br s, $2 \mathrm{H}, \mathrm{C}_{2}-\mathrm{NH}_{2}$ ); 3.83, 3.76, 3.74 $(\mathrm{m}, 12 \mathrm{H}, 4 \times \mathrm{OMe}) .{ }^{13} \mathrm{C}$ NMR (DMSO-d $\left.d_{6}\right): \delta=163.7(\mathrm{C}-2) ; 161.7$ (C-4), 160.9 (C-6), 151.8, $147.0(4 \times C-\mathrm{OMe})$; 141.0 (C-1'); 131.9, 131.4, 131.3, 129.2, 128.7, $128.5\left(\mathrm{C}_{\text {arom }}\right) ; 122.9$ (C-5); 113.5, 112.1, $110.3\left(\mathrm{C}_{\text {arom }}\right) ; 55.1$ (4×OMe). Anal. calcd. For $\mathrm{C}_{26} \mathrm{H}_{26} \mathrm{~N}_{6} \mathrm{O}_{4}$ (486.52): C, 64.19; H, 5.39; N, 17.27. Found: C, 64.56; H, 5.31; N, 17.20 .

\section{2,6-Diamino-4-(2-benzylhydrazinyl)-5-(2'-fluoro-[1,1'-biphenyl]-4-yl)pyrimidine (14).}

From 5 (70 mg, $0.19 \mathrm{mmol})$ and $o$-fluorophenylboronic acid $(27 \mathrm{mg}, 0.19 \mathrm{mmol})$. Yield: $63 \mathrm{mg}(78 \%)$, as a brown crystals, m.p. $180-182{ }^{\circ} \mathrm{C}(\mathrm{dec}), \mathrm{R}_{\mathrm{f}}=0.67$ (eluent: etheyl acetate/ hexane $\left.3: 2\right) .{ }^{1} \mathrm{H}$ NMR $\left(\mathrm{DMSO}-d_{6}\right)$ : $\delta=8.03$ (br s., $\left.2 \mathrm{H}, \mathrm{C}_{6}-\mathrm{NH}_{2}\right)$. 7.82-7.67 (m, 4H, $\left.\mathrm{C}_{2}-\mathrm{NH}_{2}+2 \mathrm{xNH}\right) ; 7.64-7.31\left(\mathrm{~m}, 13 \mathrm{H}, \mathrm{H}_{\text {arom }}\right) ; 4.31(\mathrm{~d}, 2 \mathrm{H}, J=5.5$ $\left.\mathrm{Hz}, \mathrm{CH}_{2}\right) .{ }^{13} \mathrm{C}$ NMR (DMSO- $\left.d_{6}\right): \delta=166.9(\mathrm{C}-4) ; 162.1(\mathrm{C}-2) ; 161.1\left(\mathrm{~d}, J_{\mathrm{C} 4 ", \mathrm{~F}}=250 \mathrm{~Hz}, \mathrm{C}_{4 "-\mathrm{F}}\right) ; 152.2(\mathrm{C}-6)$; $139.5\left(\mathrm{C}-4^{\prime}+\mathrm{C}_{\text {phenylhydraz. }}^{1}\right) ; 139.2\left(\mathrm{~d}, J_{\mathrm{C}-1 \text { ",F }}=2.4 \mathrm{~Hz}, \mathrm{C}-1 "\right) ; 133.9,133.1,131.9,131.4,129.2,128.7,128.6$, 127.2, $119.2\left(\mathrm{C}_{\text {arom }}\right) ; 104.7(\mathrm{C}-5) ; 55.4\left(\mathrm{CH}_{2}\right)$. Anal. calcd. for $\mathrm{C}_{23} \mathrm{H}_{21} \mathrm{FN}_{8}$ (428.46): C, 64.47; H, 4.94; N, 26.15. Found: C, 64.24; H, 4.90; N, 25.94.

\section{2,6-Diamino-4-(4-nitrophenyl)-5-(4-nitro[1,1'-biphenyl]-4-yl)pyrimidine (15).}

From $2(213 \mathrm{mg}, 0.75 \mathrm{mmol})$ and 4-nitrophenylboronic acid 11 (250 mg, $1.50 \mathrm{mmol})$. Yield: $323 \mathrm{mg}$, (94\%), as a red crystals, m.p. $185-187{ }^{\circ} \mathrm{C}, \mathrm{R}_{\mathrm{f}}=0.70$ (eluent: etheyl acetate/ hexane $\left.2: 1\right) .{ }^{1} \mathrm{H}$ NMR (DMSO- $\left.d_{6}\right)$ : $\delta=9.24\left(\mathrm{~s}, 2 \mathrm{H}, \mathrm{C}_{6}-\mathrm{NH}_{2}\right) ; 8.16-6.96\left(\mathrm{~m}, 12 \mathrm{H}, \mathrm{H}_{\text {arom }}\right) ; 6.94\left(\mathrm{~s}, 2 \mathrm{H}, \mathrm{C}_{2}-\mathrm{NH}_{2}\right) .{ }^{13} \mathrm{C}$ NMR $\left(\mathrm{DMSO}-d_{6}\right): \delta=164.5(\mathrm{C}-$

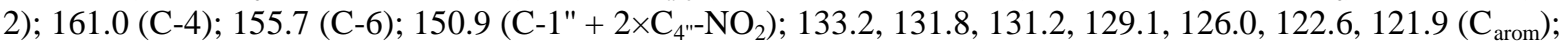
118.5 (C-5). Anal. calcd. For $\mathrm{C}_{22} \mathrm{H}_{16} \mathrm{~N}_{8} \mathrm{O}_{4}$ (456.41): C, 57.89; H, 3.53; N, 24.55. Found: C, 57.76; H, 3.48; N, 24.71 .

\section{General procedure for preparation of 6-amino-4-methoxy-N,N-dimethyl-6-arylpyrimidines 20-23 via} Suzuki reaction.

A suspension of 2-amino-4-chloro-6-methoxy- $N, N$-dimethylpyrimidine $\mathbf{1 6}$ and arylboronic acid in $n$ propanol $(15 \mathrm{~mL})$, then it was stirring for 15 minute until the solid was dissolved. To this solution $\mathrm{Pd}(\mathrm{OAc})_{4}$ (360 mg, $0.11 \mathrm{mmol}), \mathrm{Ph}_{3} \mathrm{P}(128 \mathrm{mg}, 0.49 \mathrm{mmol})$ and $2 \mathrm{M}$ aq. solution of $\mathrm{Na}_{2} \mathrm{CO}_{3}(4 \mathrm{~mL})$ was added. The reaction mixture was refluxed under nitrogen for 4-8 $\mathrm{h}$, and the reaction progress was monitored by TLC (eluent: etheyl acetate/ hexane 1:1). After cooling, the reaction mixture was filtered, and concentrated under vaccum. The solid product was filtered and washed with cold ether to give the desired product.

\section{2-Amino-4-methoxy-N,N-dimethyl-6-(4-nitrophenyl)pyrimidine (20).}

From 16 (100 mg, $0.53 \mathrm{mmol})$ and p-nitrophenolboronic acid 11 (89 mg, $0.53 \mathrm{mmol})$. Yield: $100 \mathrm{mg}$ $(68 \%)$, as a green crystals, m.p. $137-139{ }^{\circ} \mathrm{C}, \mathrm{R}_{\mathrm{f}}=0.40 .{ }^{1} \mathrm{H}$ NMR (DMSO- $\left.d_{6}\right): \delta=8.35-8.16\left(\mathrm{~m}, 4 \mathrm{H}, \mathrm{H}_{\text {arom }}\right) ; 6.72$ (s, 1H, H-5), 3.92 (s, 3H, OMe), $3.21\left(\mathrm{~s}, 6 \mathrm{H}, \mathrm{NMe}_{2}\right) .{ }^{13} \mathrm{C}$ NMR (DMSO-d $): \delta=171.2(\mathrm{C}-4) ; 162.2(\mathrm{C}-2+\mathrm{C}-6)$; $148.8\left(\mathrm{C}_{4^{\prime}}-\mathrm{NO}_{2}\right) ; 143.8\left(\mathrm{C}_{\text {arom }} 1^{\prime}\right) ; 128.4\left(\mathrm{C}_{\text {arom }}-2^{\prime}+\mathrm{C}_{\text {arom }}-6^{\prime}\right) ; 124.1\left(\mathrm{C}_{\text {arom }}-3^{\prime}+\mathrm{C}_{\text {arom }}-5^{\prime}\right) ; 92.5(\mathrm{C}-5) ; 53.5(\mathrm{OMe})$; $36.9\left(\mathrm{NMe}_{2}\right)$. Anal. calcd. For $\mathrm{C}_{13} \mathrm{H}_{14} \mathrm{~N}_{4} \mathrm{O}_{3}(274.28)$ : C, 56.93; H, 5.14; N, 20.43. Found: C, 56.71; H, 5.02; N, 20.21 .

\section{3-(2-(N,N-Dimethylamino)-6-methoxypyrimidin-4-yl)benzoic acid (21).}

From 16 (100 mg, $0.53 \mathrm{mmol})$, and 3-boronobenzoic acid 17 (88 mg, $0.53 \mathrm{mmol})$. Yield: $85 \mathrm{mg}$ $(59 \%)$, as a white powder, m.p. $>300{ }^{\circ} \mathrm{C}$ (dec.), $\mathrm{R}_{\mathrm{f}}=0.60 .{ }^{1} \mathrm{H}$ NMR (DMSO- $\left.d_{6}\right): \delta=10.45\left(\mathrm{~s}, 1 \mathrm{H}, \mathrm{CO}_{2} \mathrm{H}\right) ; 8.29-$ $8.02\left(\mathrm{~m}, 4 \mathrm{H}, \mathrm{H}_{\mathrm{arom}}\right) ; 6.62(\mathrm{~s}, 1 \mathrm{H}, \mathrm{H}-5) ; 3.90\left(\mathrm{~s}, 3 \mathrm{H}, \mathrm{C}_{4}-\mathrm{OMe}\right) ; 3.20\left(\mathrm{~s}, 6 \mathrm{H}, \mathrm{NMe}_{2}\right) .{ }^{13} \mathrm{C}$ NMR $\left(\mathrm{DMSO}-d_{6}\right): \delta$ $=173.4\left(\mathrm{CO}_{2} \mathrm{H}\right) ; 170.5(\mathrm{C}-4) ; 162.7(\mathrm{C}-6) ; 161.7(\mathrm{C}-2) ; 132.2,130.9,129.6,129.1,128.7\left(\mathrm{C}_{\text {arom }}\right)$; $91.4(\mathrm{C}-5)$; $52.8(\mathrm{OMe}) ; 36.3\left(\mathrm{NMe}_{2}\right)$. Anal. calcd. For $\mathrm{C}_{14} \mathrm{H}_{15} \mathrm{~N}_{3} \mathrm{O}_{3}$ (273.29): C, 61.53; H, 5.53; N, 15.38. Found: C, 61.32; $\mathrm{H}, 5.41 ; \mathrm{N}, 15.17$. 


\section{2-Amino-4-(2-fluorophenyl)-6-methoxy-N,N-dimethylpyrimidine (22).}

From 16 (100 mg, $0.53 \mathrm{mmol})$ and 2-(fluoro)phenylboronic acid 18 (75 mg, $0.53 \mathrm{mmol})$. Yield: 96 $\mathrm{mg},(73 \%)$, as a yellowish powder, m.p. $249-253{ }^{\circ} \mathrm{C}, \mathrm{R}_{\mathrm{f}}=0.48 .{ }^{1} \mathrm{H}$ NMR (DMSO- $\left.d_{6}\right): \delta=7.81-7.43(\mathrm{~m}, 4 \mathrm{H}$, $\left.\mathrm{H}_{\text {arom }}\right) ; 6.82(\mathrm{~s}, 1 \mathrm{H}, \mathrm{H}-5) ; 3.82\left(\mathrm{~s}, 3 \mathrm{H}, \mathrm{C}_{4}-\mathrm{OMe}\right) ; 3.13\left(\mathrm{~s}, 6 \mathrm{H}, \mathrm{NMe}_{2}\right) .{ }^{13} \mathrm{C} \mathrm{NMR}\left(\mathrm{DMSO}-d_{6}\right): \delta=171.8(\mathrm{C}-4)$; 164.4 (C-6); $161.1(\mathrm{C}-2) ; 156.6\left(\mathrm{~d}, J_{\mathrm{C}^{\prime}, \mathrm{F}}=251 \mathrm{~Hz}, \mathrm{C}_{2}-\mathrm{F}\right) ; 129.2,129.1,128.8,127.5,125.4,122.9 .115 .1(\mathrm{~m}$, $J_{\mathrm{C}, \mathrm{F}}$ couplings, $\left.\mathrm{C}_{\text {arom}}\right) ; 95.0(\mathrm{C}-5) ; 53.5(\mathrm{OMe}) ; 36.8\left(\mathrm{NMe}_{2}\right)$. Anal. calcd. For $\mathrm{C}_{13} \mathrm{H}_{14} \mathrm{FN}_{3} \mathrm{O}(247.27)$ : C, 63.15; H, 5.71; N, 16.99. Found: C, 62.90; H, 5.65; N, 15.82 .

\section{5-(2-(Dimethylamino)-6-methoxypyrimidin-4-yl)furan-2-carbaldehyde (23).}

From 16 (200 mg, $1.07 \mathrm{mmol})$ and (5-formyl-2-yl)boronic acid 19 (150 mg, $1.07 \mathrm{mmol})$. Yield: 177 $\mathrm{mg}(67 \%)$, as a pale brown powder, m.p. $248-250{ }^{\circ} \mathrm{C}$ (dec.), $\mathrm{R}_{\mathrm{f}}=0.61 .{ }^{1} \mathrm{H} \mathrm{NMR}\left(\mathrm{DMSO}-d_{6}\right): \delta=10.54(\mathrm{~s}, 1 \mathrm{H}$, $\mathrm{CHO}) ; 8.58\left(\mathrm{~d}, 1 \mathrm{H}, J=5.2 \mathrm{~Hz}, \mathrm{H}_{\text {furan }}{ }^{-4}\right) ; 7.96\left(\mathrm{~d}, 1 \mathrm{H}, J=5.2 \mathrm{~Hz}, \mathrm{H}_{\text {furan }}{ }^{-3}\right) ; 6.83$ (s, 1H, H-5); 4.25 (s, 3H, $\mathrm{OMe}$ ); 2.94 (s, 6H, $\mathrm{NMe}_{2}$ ). ${ }^{13} \mathrm{C}$ NMR (DMSO- $\left.d_{6}\right): \delta=178.5(\mathrm{CHO}) ; 170.3$ (C-4); 167.4 (C-6); $163.1(\mathrm{C}-2)$; $161.1\left(\mathrm{C}_{\text {furan }}-1^{\prime}\right) ; 152.3(\mathrm{C}-\mathrm{CHO}) ; 124.6\left(\mathrm{C}_{\text {furan }}-3^{\prime}\right) ; 111.8\left(\mathrm{C}_{\text {furan }}-2{ }^{\prime}\right) ; 102.3(\mathrm{C}-5) ; 53.8(\mathrm{OMe}) ; 38.1\left(\mathrm{NMe}_{2}\right)$. Anal. calcd. For $\mathrm{C}_{12} \mathrm{H}_{13} \mathrm{~N}_{3} \mathrm{O}_{3}$ (274.25): C, 58.29; H, 5.30; N, 16.99. Found: C, 58.02; H, 5.22; N, 16.42.

\section{Biology \\ Tested Microbes}

The antimicrobial effects of the fourteen synthetic organic compounds (under test) were experimented on the different local pathogenic isolates of gram positive bacteria (10 isolates of Staphylococcus aureus, 10 isolates of Staphylococcus saprophyticus and 10 isolates of Streptococcus pyogenes), gram negative bacteria (10 isolates of Escherichia coli, 10 isolates of Klebsiella pneumonia and 10 isolates of Pseudomonas aeruginosa) and some of the clinically important yeast (10 isolates of Candida albicans and 10 isolates of Candida glabrata). All these isolates were gathered from the advanced microbiology lab, Biology departments in faculty of science- Babylon University, Iraq.

\section{Well Diffusion Method}

The synthetic organic compounds were used for studying their antibacterial activity. A loop full of the experimented isolates of bacteria or fungus was inoculated in $30 \mathrm{~mL}$ of Nutrient broth in a conical flask and incubated for 72 hrs to get active strain by using agar well diffusion method. Muller Hinton Agar (or Potato dextrose agar for fungus) was poured into Petri dishes. After solidification $0.25 \mathrm{ml}$ of test, strains were inoculated in the media separately. Care was taken to ensure proper homogenization. The experiment was performed under strict aseptic conditions. After the medium solidified, a well was made in the plates with sterile borer $(5 \mathrm{~mm})$. The compound $(50 \mu \mathrm{l})$ was introduced into the well and plates were incubated at $37^{\circ} \mathrm{C}$ for $72 \mathrm{hrs}$. All samples were tested in triplicates. Microbial growth was determined by measuring the diameter of zone of inhibition [20]

\section{ACKNOWLEDGEMENTS}

We thank Mr. U. Haunz and Miss A. Friemel of chemistry department, University of Konstanz, Germany for NMR experiments.

[1.] Gabriel. S.; Colman. J, Ber. Dtsch. Chem. Ges. 1899, 32, 1536

[2.] Kappe. C. O. Tetrahedron 1993, 49, 6937-6963 (review).

[3.] Stenbuck. P.; H. M. Hood, US Patent 62, 3,049,544, 1962.

[4.] Kidwai. M.; Saxena. S.; Rastogi. S.; Venkataramanan. R. Curr. Med. Chem.-Anti-Infect. Agents 2003, $24,269-286$.

[5.] Jain. M. K.; Sharnevsas. S. C. organic chemistry, III edition, 2008, 997-999.

[6.] Heidelberger. C.; Chaudhuri. N. K.; Danneberg.P.; Mooren. D.; Griesbach. L.; R., Duschinsky. R.; Schnitzer. J.; Pleven. E.; Scheiner. J. Nature 1957, 179, 663-666.

[7.] Fröhlich. L. G.; Kotsonis. P.; Traub. H.; Taghavi-Moghadam.S.; Al-Masoudi. N.; Strobel. H.; Matter.H.; Pfleiderer. H. W. J. Med. Chem. 1999, 42, 4108-4121.

[8.] Stanforth. S. P. Tetrahedron 1998, 54, 263-303.

[9.] Miyaura. N.; Yamada. K.; Suzuki. A. Tetrahedron Lett. 1979, 20, 3437-3440.

[10.] Miyaura. N.; Suzuki. A. Chem. Comm. 1979, 19, 866-867.

[11.] Miyaura. N.; Suzuki. A. Chem. Rev. 1995, 95, 2457-2483.

[12.] Gribble. J. J. Li, G. W. Palladium in Heterocyclic Chemistry; Tetrahedron Organic Chemistry Series; Pergamon: Amsterdam, 2000; Vol. 20.

[13.] Davis. A. L.; Keeler J.; Laue. E. D.; Moskau. D. J. Magn. Reson. 1992, 98, 207-216.

[14.] Marichal. P.; Koymans. L.; Willemsens. S.; et al. Microbiology 1999; 145(Pt10):2701-13.

[15.] Nikadio. X. Li, H. Drug. 2009, 69 (12):1555-623.

[16.] Kanafani. Z.A.; Perfect. J.R. Clinical Infectious Diseases. 2008, 46:120-8.

[17.] Sanglard. D.; Bille. J. Washington, DC: ASM Press, 2002:349-83.

[18.] Mellado. E.; Garcia-Effron. G.; Alcazar-Fuoli. L.; Cuenca-Estrella. M.; Rodriguez- Tudela. J.L.; Antimicrob Agents Chemother. 2004, 48:2747-50.

[19.] Mellado. E.; Garcia-Effron. G.; Alcazar-Fuoli. L.; Cuenca-Estrella. M.; Rodriguez- Tudela. J.L. Antimicrob Agents Chemother. 2007, 51:1897-904.

[20.] Clinical and Laboratory Standards Institute (CLSI).Twentieth Informational Supplement. 2010, M100-S20; Vol. 30 No. 1 Replaces M100-S19 Vol. 29 No. 3: 1-157. 